\title{
Ten Thousand Cells per Kilogram
}

National Cancer Institute

\section{Source}

National Cancer Institute. Ten Thousand Cells per Kilogram. NCI Thesaurus. Code C67257.

A derived unit expressed as a number of cells in tens of thousands per unit of mass equal to one kilogram. 